\title{
What Is Bahai Orientalism?
}

\author{
Geoffrey Nash
}

check for updates

Citation: Nash, Geoffrey. 2021. What Is Bahai Orientalism? Humanities 10:

2. https://doi.org/10.3390/ h10010002

Received: 19 November 2020 Accepted: 14 December 2020 Published: 23 December 2020

Publisher's Note: MDPI stays neutral with regard to jurisdictional clai$\mathrm{ms}$ in published maps and institutional affiliations.

Copyright: $\odot 2020$ by the author. Licensee MDPI, Basel, Switzerland. This article is an open access article distributed under the terms and conditions of the Creative Commons Attribution (CC BY) license (https:// creativecommons.org/licenses/by/ $4.0 /)$.
Independent Scholar, Durham DH1 5LD, UK; geoff.nash6@outlook.com

\begin{abstract}
Scrutinizing the literature of a modern religious movement this article argues that postcolonial theory can effectively be brought to the analysis of religions and religious writing. The case study focuses on the way in which colonialism impacted the Bahai faith in a specific and formative way, causing its leadership to present aspects of the faith's development by employing the codes of Western Orientalism. Drawing on nineteenth and early twentieth-century European orientalist texts composed either about their own faith, or the Islamic society out of which it grew, the article demonstrates how these led Bahais "themselves [to] ... adopt [..] an essentially Orientalist vision of their own community and of Iranian society". Edward Said's Orientalism throws light on an enduring situation in which mutual othering has crossed from culture and religion into politics, however since the late 1990s critics have demonstrated that Orientalism can function in more varied ways than Said allowed. Finally, the possibility is discussed as to whether there can be such a thing as a postcolonial Bahai scholar.
\end{abstract}

Keywords: postcolonialism; Bab; Bahai faith; Orientalism; self-orientalizing; modernity; Shoghi Effendi

\section{Introduction}

The aim of this article is to demonstrate how postcolonial approaches, which since the beginning of the new millennium have been insightfully deployed in the study of Christianity, can be usefully applied to other world religions. However, in discussing the impact Orientalism and postcolonialism have had or might have on religious studies in this article, I eschew disciplinary issues such as the subject's discreteness, its place within culture, the scientific study of religion and so on. I start out from the premise that Edward Said's Orientalism was a foundational text in the development of postcolonial approaches generally, owing to the impulse it brought to our awareness of the imperial production of knowledge and its processes, in which studying, analyzing, and reporting on non-Western cultures took the form it did, privileging Western norms and objectifying, essentializing, diminishing, and debasing the non-Western. A prevalent view of postcolonialists is that Said re-oriented analysis of the humanities collectively (as followed up in the postcolonial turn) making them alive to cultural bias towards non-Western societies in the name of Western conceptions of modernity. One outcome of applying a postcolonial approach to religious studies devolves from the typically Saidian position of contesting the Academy's separation of humanities into discrete subjects within disciplinary boundaries, leading to the assumption that religion is separate from politics, and that there should be separate departments of religion, political science, economics et cetera. This is precisely the point made by Richard Horsley in his discussion of the "depoliticization of Jesus" in Jesus and Empire (Horsley 2003, p. 6). It is affirmed in Brett's Decolonizing God (Brett 2008) and the founding of the Postcolonial Theology Network. Richard King in Orientalism and Religion (King 1999) focuses on Said's theory as enabling understanding of the way in which "the academic discipline of religious studies has contributed to the construction of the object of its analysis, creating a textualized, homogeneous and limited group of world religions largely constructed in its own (modern, Western) image." Noting the word "Orientalism" has in itself come to carry a pejorative meaning he also points out that Said, "acknowledges elsewhere that there is an authentic 'Orient' out there that is actively being misrepresented" 
(King 1999, pp. 82-83). Drawing upon Talal Asad's observations on colonial anthropology, Kiri Paramore in his recent collection of essays Religion and Orientalism in Asian Studies, affirms "essentialist religion-centred representations of culture have been used to project a vision of ... colonized ... cultures and countries, which is clearly defined to stand against a normative standard of modernity" (Paramore 2016, p. 129).

In line with how the term has come to be understood after Foucault, throughout my article the words "writing" and "narrative" are taken as modes of discourse. Said produced a modification of Foucault in his conception of "Orientalist discourse": in Orientalism an author, literature-oriented approach can be seen to operate across a wide range of writing by composers of texts such as poets, novelists, philosophers, political theorists, economists and imperial administrators (Said 2003; Nash 2019). To this I add the writing of religious leaders, thinkers and apologists. Said however had little to say about Orientalism's relation to religion per se and although Islam and Islamic culture featured prominently in Orientalism its subject was not Islam, "but rather the portrayal of Islam in the West, offering a critique of the foundations and the goals upon which the coverage is based" (Viswanathan 2001, p. 437). Patrick Williams confirms: "One of the foundational acts of postcolonialism, [Orientalism] is among other things an engagement with the West's construction of, demonisation of, and subsequent assaults upon, Muslim identity and culture" (Williams 2014, p. 48). Western dominance is the starting point in Saidian Orientalism and this transfers to postcolonialism. The main focus of the article is the manner in which power and knowledge are linked in the production of Orientalist discourse, particularly in the way it "others" its objects who, in the case of Orientalism and in this article too, are mainly Muslims.

\section{Empire, Christianity, and the Babi and Bahai Movements}

In the topic I have chosen to write about postcolonial analysis alerts us to the imperial dimensions behind the birthing of a new eastern religion. The focus here is on the nineteenth-century Islamicate world and on a faith which traces its origin to an Iranian Mahdi. Ali Muhammad Shirazi, or the Bab as he is more generally known, was the founder of a movement whose followers staged a number of uprisings in Iran in the late 1840s. After the Bab was executed in 1850, the remaining Babi leaders were exiled to Ottoman domains where Babism was re-launched and came to be known as Bahaism, after its founder Bahaullah, a former Babi. In the first decade of the twentieth century, the movement spread to North America and Western Europe where it was further modified in the hands of Bahaullah's eldest son and designated successor Abdul Baha also known as Abbas Effendi, after whom a street on Mount Carmel was posthumously named. He was an outstanding notable still embedded in the Islamic character of the Akka and Haifa areas of Palestine. In the local mosque and on the occasion coinciding with the opening of the Woking Mosque near London in 1912, Abdul Baha maintained the formalities of Islamic worship. However, liberal clergymen in Britain and colonial officials and leading military figures in Palestine tended not to associate him with the Islamicate world. (Interestingly, the Military Governor of Jerusalem Ronald Storrs described him dressed in white robes "noble as a Prophet of Michael Angelo" rather than, say, a Sufi shaykh) (Storrs 1939, p. 232). Bahais were inspired by Abdul Baha, who journeyed to Europe and North America between 1911 and 1912, to exchange Islamic terms of reference (though not the many Islamicate concepts Bahaism contains) for a cosmopolitan message of peace and world unity encoded within a discourse of religious modernity and addressed to a world stage. However, it was under the aegis of Shoghi Effendi, a grandson of Abdul Baha who appointed him to the Guardianship (wilaya) of the Bahai faith that it self-identified as a new religion. Todd Lawson conceives of this as "perhaps the only 'Islamic movement' of recent history to have 'escaped the gravitational pull of Islam' and acquired a distinctive post-Islamic identity" (Lawson 2012, p. 468). Bahais usually see this process as divinely ordained and proceeding in orderly managed stages-we shall see later whether this model can be gainfully viewed from a postcolonial perspective. The core situation of hostility and persecution that often faces 
movements of renovation in Islamicate domains can throw them on to the defensive, as might be considered the case with the Bahais. However, we shall see that the orientation their movement adopted in making colonial writers their allies raised a set of issues that are the main focus of this article.

With respect to modern millenarian movements, Moshe Sharon argues "there is no underlying connection between the spiritual developments in the East and those in Europe and America"; but he makes the Bahai faith the exception: "in moving westwards [it] arguably became the only one to move outside of its hinterland and make the journey from East to West moving outside the scope of its religious origins" (Sharon 2004, p. 7). As followers of a new religion from the Middle East, Bahais entered the space already opened in the United States by nineteenth-century Christian millenarian movements. New religious sects-Mormons, Adventists, Jehovah's witnesses-shared a common heritage with respect to the millennium and the expectancy it generated for the return of Christ. Though in Iran Babism might be said to have emerged out of a comparable environment of chiliastic Shiism, once within the orbit of Christianity, Bahaism quickly switched its millennial vocabulary and discourse register. When converts to the new religion started to show up in the United States and Western Europe in the early years of the twentieth century, a trickle of whom held positions in Christian organizations, they quickly assimilated Bahai norms to Christianity. Missionaries in Iran who had spent many, largely unfruitful decades attempting to convert Iranian Muslims found further frustration in their encounter with Bahais; transferring their antagonism to the West some became adversaries in print using material written by orientalists to undermine Bahai claims. However, Orientalist attempts to reduce Islam such as that performed by the missionary-academic in India, William Muir, would not work with Bahaism whose chief, Shoghi Effendi, ironically, would in the course of time direct similar texts against Islam. As Bahais moved under pressure of exile from Iran to the Ottoman Empire, and later to America, a universalizing Christian bent was developed. The encounter was intrinsic to the process of change from an Islamic to a post-Islamic movement. This began before Shoghi Effendi's Guardianship, but it was his decision to combine Orientalism and Christianizing bringing these together in the Bahai narrative.

\section{Construction(s) of Bahai Orientalism}

The Bahai faith has adopted a universal, reformist stance that allows for alignment with formulations of Western modernity. Bahai leaders, however, have had very little to say about imperialism and the dominion of the West, and tended to endorse Western rule in the East under the rubric of "obedience to rulers". Orientalism being the dominant apparatus for relaying notions about the East in the era of Empire, depictions of Islam as a backward, stagnant element in eastern societies certainly attracted Western Bahais. Idioms dilating on Persia's "medieval" backwardness started to feature in Bahai writing in statements about Muslim opponents in Iran in the 1900s and the culture of Iranians in general. Although officially non-political, among many Iranian Bahais there also developed in the 1930s support for the Pahlavi form of dynastic nationalism with its strong connections to Western Orientalism (Nash forthcoming). The individual most influential in the process of the construction of a Bahai Orientalism was and continues to be Shoghi Effendi. It is from his writings that evidence for the argument will mainly be drawn.

According to Denis MacEoin, the "influence of Shoghi Effendi's orientalist vision of the Babi-Baha'i movement on later Baha'i writing in the West has been profound and enduring" (MacEoin 2009, p. 533). An ethnic Iranian born in Palestine in 1897 and brought up in a predominantly Persian speech-community, associating in his early adult years with British colonial administrators, high-ranking military officers, orientalists, and Western Bahai figures from wealthy and professional backgrounds, as a religious leader Shoghi Effendi occupied a niche and decidedly ambiguous position in the newly transplanted British colonial outpost in the Middle East. Marked out to play the role of interpreter of Bahai doctrine and becoming the architect of a far flung administration, he was educated 
at the Syrian Protestant College in Beirut then sent to Oxford University in 1920. There he gained an exceptional proficiency in English, a language in which none of the three founder-figures of the faith had been able to communicate. Having mastered the codes of formality of the dominant world imperial power he brought this expertise to the newly centralized Bahai World Center situated on Mount Carmel. Performance of his role as Guardian of the faith coincided with the situation of "double colonialism" in which the British administered the native Arab and oriental populations while the Zionist movement took over the land of Palestine (Thompson 2019, p. 5). Called back to Haifa at the close of 1921 on the death of Abdul Baha, Shoghi Effendi largely detached himself from the oriental locale his grandfather had moved in. He discarded eastern dress (with the exception of a karakul hat) and cutting off intercourse with locals altogether received mainly British and Zionist VIPs (Khanum 1969).

Beginning in Palestine in the 1920s, almost single-handedly a Bahai literature in English was scripted by the Guardian until his death in 1957. This took the form of translations from the Arabic and Persian writings of the founders, and lengthy letters addressed to the believers which were eventually collated into volumes, together with several histories. Collectively, these laid down the doctrine of, and established a canonical narrative for the Bahai faith. Behind Shoghi Effendi's heavily derivative style of writing drawn from eighteenth-century and Victorian prosody with its syntactically complex sentences and Latinate vocabulary can be discerned a mindset to which the term "selforientalizing" Westerner can most effectively be applied. Having had no direct personal contact with the land of his ancestors, an imaginative geography of Persia (the term he always used) came to him via the writings of the Bahai holy figures and his reading of Western writers, in the main historians, travelers and orientalists. Together these influences worked towards his construction of an image that was both negative and othering of the land and its people, its culture, and its religion, and by extension of other adjoining Middle Eastern spaces. While following the tenets of Bahaullah and Abdul Baha that upheld the prophethood of Muhammad and revelation of the Quran, Shoghi Effendi shaped a narrative condemning the Islamic world for rejecting the claims of Bahaullah. Although probably unavoidable given the continuing hostility to which the Bahais were subject in Iran and to a lesser extent elsewhere in the region, through being couched in Orientalist terms and inflected with Christian motifs this narrative oriented the Bahai faith in a new, pro-Western direction. From his reading of Western writers he borrowed and incorporated into his writings the classic Orientalist division of progressive civilization (implicitly recognized as embodied in the modernity authored by the West) regarding de haut en bas a backward, rigid and fanatical Orient. In particular, this negative view focused Persia's decadence and the part played in it by "arrogant, fanatical, perfidious and retrograde clericals" and to a more muted degree its Qajar rulers (Shoghi Effendi 1961, p. 95). The late nineteenth-century writings on Persia of British author George Nathaniel Curzon were especially chosen to aid this project. Gesturing to the Aryan-Persianism explored earlier in the century by John Malcolm, Henry Rawlinson, Arthur Gobineau, Ernest Renan, and latterly Edward Granville Browne, Curzon suited Shoghi Effendi's preference for authors who stressed the self-evident irreversibility of Persia and Islam's decline. To this he added a component that operated as a binary opposite: the huge assertion of an exclusive agency of redemption in the form of a unitary Babi-Bahai revelation. These were the two pillars upon which Shoghi Effendi's Bahai narratives were constructed, and vital to them both was the input Western orientalists provided, some of whom had mentioned Bahaism as possibly replacing Islam as Persia's established religion. Probably because they were considered "modern" these writers also inflated the number of Bahais there (e.g., Curzon 1892, vol. 1, p. 499), perhaps on the assumption that if they took over the country, they would be friendly to Britain. Not potentially rebellious as the Muslims of the Empire were thought to be, as a small quietist group in Palestine, and like other heterodox Muslim sects scattered through the Empire such as the Ismailis and Ahmadiyya, they not only posed no threat, but positively exuded declarations of loyalty. In Britain, Bahai converts were never considered to be "the enemy 
within" as were a few high-profile British Muslim converts like Abdullah Quilliam and Muhammad Marmaduke Pickthall who both supported Ottoman Turkey.

Abdul Baha spent most of his life in the Ottoman Empire and wrote in Turkish, one of the three oriental languages in which Shoghi Efendi was also fluent. The nineteenthcentury Bahai movement favored similar notions concerning modernization to the Ottoman Tanzimat. However, two of its ministers-Ali Pasha and Fuad Pasha-were responsible for exiling Bahaullah and his family to Akka thus creating a gulf that was unassailable (Cole 1992). Later, the fin de siècle Ottoman elite developed an Ottoman form of Orientalism the main idea of which was to bring Western civilization to bear upon the backward peoples of their imperial domains. In order to strengthen these, in a kind of "borrowed colonialism" they created "a discourse of empire" applying Orientalist typology vis-à-vis populations living "in a state of nomadism and savagery" (Deringil 2003, pp. 312-13; Eldem 2015; Szurek 2015). Bahaullah, Denis MacEoin suggests, went as far as he could in creating a new sharia that threw out many of the outdated ordinances that also concerned Tanzimat reformers too. However, "[to] proceed too far with modification of the shari ' $a$ is, for many conservatives, to run the risk of leaving Islam entirely, as the Baha' is demonstrate" (MacEoin 2009, p. 655).

However, Shoghi Effendi's writings went even further: the major difference between the tenets of Ottoman reformers and the views he expressed is that in his, Islam features as the factor behind the East's obscurantism and as a bar to progress, whereas in theirs, it had a role as a unifying factor capable of modernization and reform (Makdisi 2002). With the defeat of 1918, the fall of the Ottoman dynasty, and the accession to power of Kemal Atatürk, Orientalism in Turkey morphed into Kemalist Orientalism, a reversion to a hard-line Western form that branded "Oriental backwardness and Muslim civilization" as equivalents, manifesting between the wars as the "anti-clerical rage" of Kemalists who saw it as "imperative to destroy 'tradition'"(Szurek 2015, p. 113; original italics). Shoghi Effendi's employment of Orientalism to pronounce on the incorrigible character of Islamic institutions aligns much more clearly with the contemporary project of Kemalist Orientalism with respect to the implacable opposition both raised against continuing Islamic entities. As Guardian he inspired the Bahai community, especially in North America, to express open support for the programs of anti-traditionalism and anti-clericalism promoted by both Atatürk and Reza Shah, in particular noting approvingly the forced Westernization of the apparel of Islamic scholars (pursued alongside the outlawing of Sufis in Turkey) and the banning of women's Islamic attire (Shoghi Effendi 1961; Nash forthcoming). The following passage presents a Muslim mullah dispossessed of his religious attire with a satirical tone unusual for Shoghi Effendi, although it strikes an obviously Orientalist, anti-clerical pose:

the once lofty turbaned, long-bearded, grave looking aqa ... as he sits, hatless, clean-shaven, in the seclusion of his home, and perhaps listening to Western music, blared upon the ethers of his native land ... Well might he muse upon the havoc which the rising tide of nationalism and scepticism has wrought in the adamantine traditions of his country. Well might he recollect the halcyon days ... seated on a donkey, and parading through the bazaars and maydans of his native land ... (Shoghi Effendi 1961, p. 68).

\section{Bringing Together East and West}

In contrast to hard-line binarism replete with negative nostrums and stereotypical tropes which fit the category set out by Edward Said, there were softer types of Orientalism to which Bahais in the first decades of the twentieth century became attached. Romantic or affirmative Orientalism valorized the spirituality and wisdom some Westerners descried in Indian philosophy and mysticism. This in turn helped stimulate a form of Occidentalism or "Orientalism in reverse" in which Indian anti-colonial activists such as Vivekananda and Mohandas Gandhi vaunted Indian spiritual superiority and condemned the West for its materialism (King 1999). Shoghi Effendi's form of Bahai Orientalism replaced a softer 
Orientalism in operation from the time of Abdul Baha which had passed into the writings of some of his Western acolytes. According to this, the mission of Bahaism was to cement the integration of eastern spirituality and Western progressive social know-how in order to bring civilization to the East and spirituality to the West. A similar approach can be found in the assimilative Orientalism of Christian universalists at broadly the same time who, though they continued to ascribe superiority to Christianity, played a prominent role in the world faiths movement initiated by the 1893 Parliament of Religions meeting in Chicago. Liberal clergymen such as T.K. Cheyne and J. Estlin Carpenter who were partly responsible for Abdul Baha's positive reception when he addressed Christian congregations in Oxford and London, were part of this tendency which valued essential spiritual values in oriental religions, although they could not find a place for Islam in their scheme (McNamara 2017).

Another eastern group advocating East-West reciprocity which had a connection with Bahaism was the Mahjar, a movement of Christian Lebanese émigré writers who had established themselves in the Americas at the beginning of the twentieth century. Primarily settled on the East coast and writing in Arabic as well as English, they started out from an assimilative perspective, constructing a universalizing project that was aimed at bringing together East and West. Both the Mahjar and Bahais of the period accepted the East/West binary but with the aim of transcending it in a blend of eastern spirituality and Western economic and civilizing progress. Citing key literary figures Ameen Rihani and Kahlil Gibran, Wail Hassan has confirmed their acceptance of "the basic premises" of Orientalism, the discrete concepts of "Orient" and "Occident". Although partially resistant they also invested in them through creating characters in their fictions who advocated cosmopolitanism and who acted as "intermediary between two worlds". However, according to Hassan while they tried to "negate Orientalist negation through Orientalist transcendence", their writings failed to accomplish what he terms the process of "cultural translation" i.e., -overcoming cultural differentials by, in this instant, disclosing the superior spiritual values of the East. So strong was Western cultural hegemonism that in their mediatory stance the Mahjar writers were unable to create harmony and equality, but still "operate[d] within the orbit of the dominant discourse" (Hassan 2011, pp. 57-58, 77).

A few avant-garde Bahai artists had links with both Mahjar figures, one of whom, Juliet Thompson arranged for Abdul Baha on his westward journeys to sit for a portrait by Gibran in his Boston studio. Ameen Rihani also incorporated Bahaism into his experimental emigrant novel, the Book of Khalid (1911). However, Hassan's argument is applicable to both movements. The fact remains that in spite of their idealism, the conditions that made this soft Orientalism possible - partly enabled by New England Orientalism but also explicable in terms of a configuration of a number of strands making for an openness to eastern influences on the part of American culture-dissipated after the Great War, continuing only in a restricted, specialized form in the poetry of Pound and Eliot (Weir 2019). Negative American Orientalist attitudes toward the East ensured that the dream of East-West unity remained unfulfilled, and it would take several generations before Middle Eastern migrant literatures began to be studied and valued in the United States. It should also be added that just as Bahaism in the early decades of the twentieth century attracted converts who articulated the movement in "New Age" terms, the same either remained largely indifferent to Islam or, having imbibed Orientalist attitudes from their Christian background, when they represented the rejection and persecution of both the Babi and Bahai movements in their native Persia drew heavily on Orientalist vocabulary (Nash forthcoming).

\section{European Orientalists and the Babi and Bahai Faiths}

We need now to return to the exceptional circumstance that led to the new oriental religion being partially inscribed in Orientalist forms, first by Western scholars and later by Bahais. It is precisely because during the Napoleonic age the country became firmly fixed in the sights of the British and French, and territorial losses at the hands of imperial Russia were set in train, that the sudden appearance of Babism in Persia first came to intersect with Orientalism. 
Qajar Iran's self-image as an empire at the center of its own universe ... changed into one of a vulnerable nation in the throes of Christian powers. Yet despite its inherent disadvantages, Qajar Iran escaped domination by colonial powers in part because of the dictates of its geography but also because of a degree of resistance displayed by the Qajar state and its subjects. (Amanat 2017, p. 179)

Abbas Amanat's introductory sketch to the Qajar period in Iran (1789-1925) gestures toward the colonial background missing from Bahai narratives; it also inscribes the Babis into the "resistance" mode he believes Persians displayed against foreign control even if, paradoxically, that resistance was raised not against any foreigner but the Qajar state. In one of the earliest Western reports on the Babis published in 1856, Lady Sheil, wife of the British Minister in Tehran, argued that they had made "a serious attempt at revolution ... under the disguise of a new revelation" and ascribed to them socialist, communist, and republican beliefs, asserting that in spite of the Bab's execution and Babi martyrdoms there was "a spirit of change abroad among the Persians, which will preserve [the Bab's] system from extinction" (Sheil 1856, pp. 176, 181). Nikkie Keddie outlined the similarities between the Babi and Chinese Taiping uprisings occurring at almost the same time against weak and corrupt dynasties, but there was not, as she suggests, a Christian infusion in Babism even if later on European orientalists tried to conjure one up (Keddie 1981, pp. 16-17).

In a work published nine years after Sheil's, French diplomat and traveler Arthur Gobineau presented the Bab and his movement to Europe on a larger scale than hitherto and was instrumental in encouraging scholars to study the Babi faith. Like Lady Sheil, he considered Persia in the 1840 s to be restless for change:

People are getting irritated with Islam, even against that strangely disfigured Islam presented by Shi'ism, finding it too narrow and restrictive ... People are looking for something else. What? (Gobineau 1957; 2009, p. 133)

Displaying Gobineau's personal predilections and idiosyncracies-including theories on the Aryan race which influenced his determination to separate the Bab from Shiism-in Religions et philosophies dans l'Asia centrale (Religions and Philosophies of Central Asia), the Bab emerges as a Christ-like figure. The outstanding components of his story-his execution and the martyrdoms of his followers-excited comparison with the beginnings of Christianity. Ernest Renan immediately picked up on his compatriot's portrait of the Bab as an Aryan messiah battling against Islam. Wholly endorsing the Christian parallels it drew, he valorized Babi martyrdom as evidence of self-sacrifice in the name of religion still being alive in the nineteenth century (Renan 1890; Nash 2014). Realizing how important sacrifice was in proselytizing the faith in the Christian West, Shoghi Effendi would employ Gobineau and Renan's encomiums on this quality (along with other European sources) in his narratives as irrefutable evidence of the kind only Western orientalists could provide.

In adopting a Western face, the Bahai movement quickly set about distancing itself from its Islamic origins. Bahaullah had attached to his Ismaili-style theophanic claim to be the latest "Manifestation" of God an ecumenical message that stretched beyond Islam and made overtures to Christian messianic expectation. Christian converts figured his relationship to Ali Muhammad as comparable to that of Christ and John the Baptist with the Bab assigned the role of Bahaullah's forerunner. It was also necessary to erase the Babis' militancy and to ascribe to the movement retrospectively the pacific character of the teachings of Bahaullah, though in the work of orientalists the Bab remained the focus rather than his successor in the Bahai scheme. Dabashi believes after the death of the Bab and in exile from Iran "Baha'ullah could not gather any politically significant community of believers" and although Bahais did perform for a while a significant reforming and modernizing role in Iran and Transcaspia their "theologically benign" movement became in time "harmless, politically innocuous and irrelevant" (Dabashi 2011, p. 202).

The strong tendency to align the Bahai faith with Christian messianic codes might well be related to Bahaullah's disengagement of his followers from political involvement, a result of his "essentially mystic world view" (Amanat 1997, p. 412). Both Bahaullah and Abdul Baha prepared the way for parallels to be drawn, which in later Bahai narratives become 
striking, between the depoliticized Jesus of Roman Christians, and Bahais' smoothing out of the political in their representations of the role and person of the Iranian Bab. The elision of the oppositional force of the Bab's movement against the Shah-mujtahid state appears to share a similar rationale to Christian decoupling of Jesus from a Jewish national revolution. While Jewish resistance to Rome was raised against an occupying power, the Babi insurgency was simultaneously a rebellion against corrupt indigenous rule, and "a revolutionary movement [with] its social and economic roots in a messianic culture now moving through major institutional transformation in the face of European colonialism" (Dabashi 2011, p. 182). Both Christians and Bahais felt the need to placate imperial power, the former because their operations came increasingly to center on Rome, while after the departure of the Ottomans, the Bahai leaders were sheltering under British imperial rule in mandated Palestine. Both Christians and Bahais saw how important it was to disconnect from resistance to imperial power staged by majority populations-Jewish in the ancient Holy Land, Muslim in the modern Islamicate ones. Placed in a postcolonial context, this phenomenon is obviously more immediate and concretely evidenced in the twentieth century record of the Bahais than in the sources Richard Horsley is able to marshal in Jesus and Empire. At least in the case of the Babi movement, it is possible to see the importance of indigenous resistance as a factor that both reappears in the Iranian Constitutional Revolution and is dissolved into an apolitical cosmopolitanism by the absent Bahai leadership.

Shoghi Effendi's incorporation of a corpus of Western European orientalists into his presentation of the history of the Bahai faith should perhaps not be considered surprising. Reza Zia-Ebrahimi points out how Iranians had an inferiority complex with regard to the West and "the sacrosanct status in which European scholarship was, and still is, held" (Zia-Ibrahimi 2011, p. 465). So although we have argued Shoghi Effendi was out of touch with the broader currents in Iran, it is undoubtedly the case that the oriental culture he had lived and imbibed among Iranian émigrés in Palestine already inclined him towards deference to Western scholarship. That this was directed to the British in particular was by no means unusual among educated persons living under the shadow of British colonialism. Among the orientalists he selects are Gobineau, Renan, Curzon and Persianist and Babi expert Edward Granville Browne. Said includes all of them in Orientalism but mentions Browne only once and misunderstands Gobineau's writings on the East because he probably never read them. The first three certainly support Said's argument that orientalists believed the Orient was aberrant and irrational, and all its glories situated in the past. Although Gobineau believed some of these aspects made "Asia" preferable to the West, Curzon's statements assert them as evidence of Persia's stagnation and as such they are conspicuously incorporated into the narrative of Bahai history. Persia and the Persian Question-in which Curzon projects his position of superiority as a British imperialist traveler to inscribe the reality of "the East" as splendid, decadent, and moribund-typifies Said's connection of Orientalism with knowledge/power. Shoghi Effendi borrowed Curzon's performance of this syndrome as a surrogate for his own narratives. Both Renan's sympathy and Browne's initial enthusiasm for Babism as an "Aryan" faith were inspired by the work of Gobineau. As a savant of Oriental culture Renan features in Said's study as an epitome of how self-selecting individuals aspired to wield the expertise of Orientalism in Renan's case in order to underwrite his ideas on race. He too joined knowledge to power in his narrative of a degraded Semitism contrasting a resurgent Aryanism, arguing that the culture produced by people of Semitic origin (pre-eminently Jews and Muslims) was now stagnant, whereas the Aryan races had created a civilization that was scientific, rational, protean, and dynamic. Edward Browne, however, complicates Said's notion of Orientalism. He did this by opposing Western dominance over the East while at the same time contributing to the export of European ideas of race and nationalism in support of the Iranian Constitutional Revolution. These ideas were later inserted into the Iranian national idea, and recent thinking has emphasized the integral role Orientalism played in the rise of eastern nationalisms (Burke 1998). 
All the figures above-mentioned feature as authorities in Shoghi Effendi's two BabiBahai narratives: Dawn-Breakers (Shoghi Effendi 1932), his "translation" or more properly his rewriting of the Bahai historian Nabil Zarandi's story of the Bab, later joined by God Passes By, a history marking the first centenary of Babi-Bahaism (Shoghi Effendi 1944). Both reference and quote from a range of orientalist texts. Nearly seventy years after Religions and Philosophies, in the introduction to Dawn-Breakers, Shoghi Effendi sets events against the background of Qajar Persia. Aided by large chunks from Persia and the Persian Question to summarize the "condition of the land", the backwardness and tyranny of the state, the chains of Islam fixing the people down, and the barbaric "Persian character", a hard-line Orientalist picture emerges:

Nothing is more shocking to the European reader, in pursuing his way through the crime-stained and bloody pages of Persian history during the last and, in a happily less degree, during the present century, than the record of savage punishments and abominable tortures, testifying alternately to the callousness of the brute and the ingenuity of the fiend. The Persian character has ever been fertile in device and indifferent to suffering; and in the field of judicial executions it has found ample scope for the exercise of both attainments. Up till quite a recent period, well within the borders of the present reign, condemned criminals have been crucified, blown from guns, buried alive, impaled, shod like horses, torn asunder by being bound to the heads of two trees bent together and then allowed to spring back to their natural position, converted into human torches, flayed while living. (Shoghi Effendi 1932, p. 20)

The creed of Islam is dispatched in a similar way:

Marvellously adapted alike to the climate, character, and occupations of those countries upon which it has laid its adamantine grip, Islam holds its votary in complete thrall from the cradle to the grave. To him, it is not only religion, it is government, philosophy, and science as well. The Muhammadan conception is not so much that of a state church as, if the phrase may be permitted, of a church state. The undergirders with which society itself is warped round are not of civil, but of ecclesiastical, fabrication; and, wrapped in this superb, if paralysing, creed, the Musulman lives in contented surrender of all volition, deems it his highest duty to worship God and to compel, or, where impossible, to despise those who do not worship Him in the spirit, and then dies in sure and certain hope of Paradise. (p. 30)

Similar tropes are employed to denigrate Islam by the Christian missionaries to Iran, but why does Shoghi Effendi re-use such material? How can a new religion be dignified by describing the land into which it was born in this degrading manner? One answer is: the more decadent and retrograde the country of the Bab and Bahaullah could be shown to be, the greater would be the contrast of their revelations and the heroic sacrifice of their followers. However, binarism-in this case refusing to ascribe any virtue to the non-Babi, non-Bahai majority of the country, especially one's religious opponents-is a message which, when repeated and ingested, is unlikely to leave open a space for reconciliation. (I found this presented no difficulty to students in Bahai institutes which I attended in the 1980s - on the contrary it confirmed everything they saw on their television screens during the Iranian Revolution and its aftermath).

Renan, who is valorized as a great authority by Shoghi Effendi, is the figure who racializes Islam as the creed of motley undistinguished peoples, only in the case of the "Aryan" Persians allowing exceptionality for standing above the "Semitism" which forms the fundamental racial character of Islam:

The Musulman East defeated the West ... Henceforth the parts are changed. European genius rises with peerless grandeur; Islamism, on the contrary, is slowly decomposing - in our days is falling with a crash ... [I]t is the appalling simplicity 
of the Semitic spirit cramping the human intellect, closing it against ... delicate

thought ... feeling ... every rational inquiry ... (Renan 1864, pp. 164-65)

Substitute 'the Bahai faith' for 'European genius' and the third sentence might be inserted directly into a Bahai text, but why are these Orientalist elements present in Bahai writing and what function do they perform? To formulate an answer we need to take into consideration matters of self-definition including: the importance of being seen to be modern, being in conformity with the New Age, showing cognizance of futures, et cetera. As well as constructing a Bahai consciousness, undoubtedly Shoghi Effendi's intention was to inform powerful figures in British government circles, in the Mandate, and VIPs more broadly as well as upcoming Zionist leaders, of the uncontentious and acculturated, modern character of the Bahai faith, in contradistinction to the Islamicate world out of which it had grown. Undeniably, his narratives are purposed as a weapon in the struggle between the Bahais and their Muslim opponents. A paradox is created, however, by Shoghi Effendi's decision to employ Orientalist and Westocentric modes of thought so unreflectively. While Orientalism and racism are closely allied, informing so much writing on the East and its peoples, the absence of racial thinking from his writing is notable, but paradigmatic, because Bahai doctrine is predicated on eradication of racism. Nonetheless, the excoriation projected in the orientalists' quotations and reproduced elsewhere in his own statements, imparts associations that unavoidably get attached to Bahai Orientalist discourse where the presentation of the growth and decay of Islamic civilization is wholly aligned with mainstream Orientalism with its teleological deployment of "periodization and direction" with Muslims assigned to the place of "existing 'local peoples' left behind in the progressive evolution of modern (European) 'civilization'" (Asad 1993, p. 13). In all these respects Bahai Orientalism aligns the Bahai faith with a Western modernity that was prevalent and hegemonic at the time but has increasingly come under fire in the postmodern world, in addition to leading Bahais to adopt "an essentially Orientalist vision of their own community and of Iranian society" (MacEoin 1988).

\section{Is There a Bahai Postcolonialist in the House?}

Western Orientalism can be said to have impacted the colonized East via the dual thrust of "missionary polemicists and academic Orientalists", with the activities of the first "aimed at all groups, but especially at Muslims". The latter, as "European scientific researchers also challenged Islam" (Lawrence 2006, pp. 144-45). In the face of that aggression, unsurprisingly, Muslims were nearly unanimous in recognizing the need to defend Islam. Islamic responses were initially mixed with modernist and revivalist elements, but in the twentieth century increasingly took on anti-imperialist, anti-Western stances. Muslim thinkers have tended to embrace the argument that Orientalism was a factor in the West's dominance over eastern countries and in the embattled situation of Islam. Bahai scholars have mainly eschewed involvement in the Orientalism debate, but it is clear that significant Orientalist elements are present in Bahai writing.

In the late nineteenth and early twentieth century the project of resistance was spearheaded by Jamal ud-Din "Afghani" and his disciple Muhammad Abdu, and then by his disciple Rashid Rida. Coterminously pro-British Indian modernists such as Sayyid Ahmad Khan, Sayyid Amir Ali, and Chiragh Ali, as well as Ahmadiyya missionaries in Europe, notably Maulana Muhammad Ali, undertook a defensive apologia against attacks on Islam by colonial missionaries and orientalists (Geaves 2018). Given that their millennial movement's antecedent, Babism underwent a struggle involving the state and religious leadership during the early nineteenth century; in the twentieth century Bahais were unable to achieve an uncontested status in Iran. In their proselytizing activities in the West Bahais were more accommodating to Christians than another Mahdi movement, the Ahmadiyya (Addison 1929). Perhaps unsurprisingly, therefore, over the matter of Orientalist attacks on Islam, Bahais were little disposed to join up to a defensive position. Bahai responses, limited and mainly low key, were conspicuous in two instances: the figure of Muhammad as a prophet and Islam as a divinely-revealed religion were publicly affirmed by Abdul 
Baha while in America, and for a period in Cairo in the late 1890s Bahai scholar Abul Fadl Gulpaygani conducted a defense of Islam "against tendentious missionaries and orientalists" (Cole 1981, p. xiii). All such efforts ended in the inter-war period with the new orientation set out by Shoghi Effendi which might be accounted as tantamount to the Bahai faith joining up with the missionaries and orientalists. From that time onward in that it takes up an Orientalist stance toward Islam in the modern world, it is logical that it should be situated within the larger scope of Orientalism.

However, to the extent that Western Bahai writers were able to approach recent and more distant periods of the history of the Islamicate world without getting too exercised by the persecution of their faith (the rejection of the Bab, Bahaullah and their truth claims), or falling into the groove of Orientalist clichés about East and West, the positive aspects of Bahai teaching allowed direction of their observations into more fruitful and worthwhile areas. For example, American Bahai author Stanwood Cobb, perhaps on account of his educationalist's mindset, in his Islamic Contributions to Civilization (1963) displayed a positive approach towards his subject that was not a universally approved one at that time in the non-Bahai world. To be fair, however, it was entirely consistent with the view expressed by Shoghi Effendi that Bahais should study the early growth and successes of Islam and indeed of other world religions. Later in the twentieth century, independent Bahai scholars operating on similar premises produced significant work on histories of the entire Islamic dispensation in which, like Cobb, they did not disclose their personal Bahai affiliations. Two outstanding examples are Hasan M. Balyuzi's Muhammad and the Course of Islam (1970) and Moojan Momen's An Introduction to Shi'i Islam (1987). A writer of mixed American-Iranian extraction, Marzieh Gail generally adopted an unpartisan approach in dealing with Persian and Arabic topics in her English writings. Her Persia and the Victorians (1951) is a detailed, low-key literature-oriented study of a subject that is replete with Orientalist associations. Since it was published around ten years before Jalal-e Ahmad's Gharbzadegi (Westoxification) it would be unfair to reprove its author for failing to show any cognizance of the connections mainstream Iranian and Arab intellectuals of the same period were starting to make on the subject of Orientalism and the Middle East (see Macfie 2000). She did however accuse E.G. Browne of behaving as a typically "authoritarian" orientalist in lamenting the lack of historical material on Babism. If Browne had only waited, she suggested, he would have been able to read the flow of books now appearing (in the late 40s and 50s) —all of them by Bahais!

In the professional academic frame, Bahais might claim more than their fair share of illustrious practitioners of Iranian Studies; however, most have either rescinded their adherence to the faith or maintained only a nominal connection (e.g., Abbas Amanat, Juan Cole, Denis MacEoin, and John Walbridge). Nonetheless, with the exception of MacEoin, whose valuable and searching interventions have supported this article, Orientalism as a field of study let alone a collection of Western conceptions of the Orient in the way Said presents is almost entirely absent from the works of the above. Abbas Amanat's chapter on the Christian missionary-orientalist Henry Martin (albeit containing only a passing reference to Babism) is however noteworthy and fascinating for the manner in which it places a noted Western missionary to Iran in the spotlight of his cross-cultural impact on mujtahids and Sufis against the background of an impending colonialism (Amanat 2005). In Modernity and the Millennium: The Genesis of the Baha'i Faith in the NineteenthCentury Middle East, expert on the history of the region Juan Cole aligns Bahaullah and Abdul Baha's pronouncements on modernity with Jeffersonian politics in an attractive way. However, he is silent about the fact that his analysis is delimited so as to totally ignore how the Bahai faith was later radically re-orientated by Shoghi Effendi, who is entirely absent from the monograph. Cole therefore has no problem in writing of the need to "get beyond Orientalist essentialisms and dichotomies", and of "the limitations of the Orientalist tradition" (Cole 1998, pp. 189-90).

Bahais are almost ubiquitously silent about Orientalism. Although it is taken for granted that many of the prominent orientalists of the mid- to late- nineteenth and early- 
twentieth centuries had something to say about Babis and/or Bahais, in Bahai scholarship generally, orientalists, even allowing for their varied individual specificities, are not delimited as a group. The fact that such a collectivity might exist is either passed over or taken as read, without even so much as an outline assessment of the place of Babi-Bahai within the broader context of the orientalism of these periods. Moojan Momen's highly informative collection of documents published in The Babi and Baha'i Religions: Some Contemporary Western Accounts (Momen 1981), many of which were written by orientalists, makes no reference to Said. Orientalism is absent from the index in Brookshaw and Fazel's The Baha'is of Iran: Socio-historical Studies (2008). A valiant exception is however to be found in an important intervention in which Stephen Lambden deconstructs a symptomatic instant of orientalist distortion of Babism: Gobineau and Browne's misattribution of Biblical learning to the Bab and Shoghi Effendi's interpolation in Dawn-Breakers of a Christ-like speech purportedly delivered by the Bab to his followers (Lambden 2002).The topic of Russian Orientalism and its relation to the Babi and Bahai faiths, because it is discrete and requires a detailed outline, has been omitted from the present article (but it forms nearly half a chapter in my forthcoming monograph). However, recent works on this subject area also leave the term "orientalism" unproblematized, and Russian military officers who came into close contact with Bahais on the borders of their empire are exonerated of all motives other than interest in their topic.

Where and how, we might ask, could postcolonial or postmodern theories interpose and stretch current Bahai thinking? To start with a beginning: like most religious narratives Bahai, particularly as articulated by Shoghi Effendi, employs a foundationalist format, one that, as suggested above, is made to unfold logocentrically. In a frequently quoted statement Shoghi Effendi sums up the Bahai faith as a teleologically directed movement that is destined to develop out of (local) Ithn' Ashariya ("Twelver") Shiism into a world religion (Shoghi Effendi 1944, p. xxi). The speaker neglects to indicate that from a historiographical perspective, the narrative approach is highly selective. Development is predicated on a treelike structure where the whole derives from a single trunk and is therefore hierarchically ordered. Postmodern analysis, however, challenges the idea that such a narrative must take on an organic development (it can, but it does not have to). In proposing their "rhizomic", model Gilles Deleuze and Félix Guatarri argue: "The rhizome is reducible neither to the One nor the multiple ... it is comprised not of units but of dimensions, or rather directions in motion" (Deleuze and Guatarri 1987, p. 21; Chicago School of Media Theory n.d.). This obviates the need to produce a linear, temporal narrative that has a fixed beginning and ordered development, one which can be critiqued on the lines that (1) it is inconsistent with the flow of life and its multidimensional character, and (2) and spatially it provides a less than satisfactory explanation of phenomena. In the case of authorized Bahai accounts of Babism for example, vital conceptions such as "return" and "renewal" are tidied up (following Bahaullah's lead in his Kitab-i Iqan) whereas scholars have considered these terms to be far more varied (and often extravagant) in their implications and associations, as is indicated in pre-Bahai Babi literature. Hasan Balyuzi did not deny the chaotic meanings and interpretations ascribed to such terms among Babis, he just wanted to see them tidied up! (Browne 1910; Balyuzi 1970, p. 73). Such is the homogenizing tendency in religious literature intent on fixing one body of truth. A reading of Babism by a postcolonial (or post postcolonial) scholar, which suggests multiple possibilities beyond Bahai or, for that matter, Shii scholasticism, is Dabashi's section in Shi'ism: A Religion of Protest.

As the present article has strongly implied, a Bahai postcolonial scholar would have to adopt a position probably even more radical than that suggested by Said's contrapuntal method: they would need to begin by deconstructing the Orientalist image in Shoghi Effendi's writings and situating the religion more firmly in its colonial contexts; but are Bahais capable of re-envisioning their tradition in this way? One factor making this difficult is the reverence with which Shoghi Effendi's writings are viewed. Another is that intellectual inquiry within present-day Bahai communities is stifled and modern/postmodern movements of thought are viewed as godless and to be avoided. Crucially, nothing can be 
written about a Bahai topic that does not pass a Bahai system of review (MacEoin 2012). Notionally, scope lies within the faith (what could be called a Bahai form of ijtihad) leaving open avenues for new thinking outside the parameters already laid down in the revelation. However, this is the province of the world governing body (the Universal House of Justice) to decide on. Hitherto progressive ideas have been disabled by the system of regulation overseen by the faith's institutions culminating in this "divinely guided" body. A similar tension obtains in the Bahai faith between conservative elders and liberal scholars as is to be found in other religious organizations, from Roman Catholic to Mormon. In the writer's opinion a huge alteration in world conditions is required before Bahais can read their foundational texts in a more revolutionary way.

\section{Conclusions}

On the level of its propagation in the West in the twentieth century the foundational Bahai narrative operated within the orbit of the dominant Western discourse of its time, mimicking what many of the intelligentsia of Western countries had been saying for a long time with respect to the Islamic Middle East and other Muslim populations. Electing to write from a self-imposed self-orientalizing perspective not unusual among modern eastern intellectuals, Shoghi Effendi accessed Orientalist tropes to help him structure a binary religious narrative in which followers of the new revelation were opposed and persecuted by those entrenched in the previous, superseded one. In it, the Bahai faith incorporates modern socio-religious beliefs in a messianic program of reform, while Shiism remains in the grip of an inexorable decline presided over by an entrenched and reactionary "clergy". Bahais acquired from the secular Christian-Enlightenment project a civilizing mission bringing progress and modernity to a Persia still coming out of its "medieval" backwardness, only instead of bringing Christianity they were re-releasing the power of the Bahai revelation in the benighted land into which it had been born. Its enemies, on the other hand, opportunely denied Bahais were followers of a religion, but branded them a political movement created by colonial powers to divide and weaken Muslims. Separating Bahaism from its Shii roots and activated in the context of its struggle with the Shii ulama and anti-Bahai Iranian intellectuals, the Bahai discourse is in reality constructed for and directed to a Western audience. In reporting the Bahai community as a movement from which a defunct Islam has been erased, but containing within this report a view of Islam that employs Orientalist tropes, such a narrative cannot be dissociated from but must be viewed as a functioning sub-discourse of Orientalism. As regards the situation of the Bahai faith's self-presentation as a religious movement that campaigns against the human rights deprivation of its followers and advocates world peace while retaining at the same time a formative Orientalist element, the outcome is what postcolonialists call aporia (Greek: "irreconcilability"). This is dangerous for a religious community to be party to, especially in the twenty-first century with rising trends of Islamophobia and anti-Semitism across the world. Under this apprehension the article makes the argument that Bahais divest themselves of the Orientalism of their foundational narrative in the cause of better promoting their positive message of world unity

Funding: This research received no external funding.

Conflicts of Interest: The author declares no conflict of interest.

\section{References}

Addison, James Thayer. 1929. The Ahmadiya Movement and its Western Propaganda. Harvard Theological Review 22: 1-32. [CrossRef] Amanat, Abbas. 1997. Pivot of the Universe: Nasir al-Din Shah Qajar and the Iranian Monarchy, 1831-1896. London: I.B. Tauris.

Amanat, Abbas. 2005. Mujtahids and Missionaries: Shi 'i response to Christian polemics in the early Qajar Period. In Religion and Society in Qajar Iran. Edited by Robert Gleave. London: Routledge Curzon, pp. 247-69.

Amanat, Abbas. 2017. Iran: A Modern History. New Haven: Yale University Press.

Asad, Talal. 1993. Genealogies of Religion: Discipline and Reasons of Power in Christianity and Islam. Baltimore: Johns Hopkins University Press.

Balyuzi, Hasan M. 1970. Edward Granville Browne and the Baha'i Faith. Oxford: George Ronald. 
Brett, Mark G. 2008. Decolonizing God: The Bible in the Tides of Empire. Sheffield: Sheffield Phoenix Press.

Browne, Edward Granville. 1910. Introduction. In Kitab-i Nuqtatu'l-Kaf. Being the Earliest History of the Babis Compiled by Hajji Mirza Jani of Kashan. Leyden: E.J.Brill, London: Luzac.

Burke, Edmund, III. 1998. Orientalism and World History: Representing Middle Eastern nationalism and Islamism in the twentieth century. Theory and Society 27: 489-507. [CrossRef]

Chicago School of Media Theory. n.d. Rhizome. Available online: https://lucian.uchicago.edu/blogs/mediatheory/keywords/ rhizome (accessed on 16 November 2020).

Cole, Juan Ricardo, ed. 1981. Mirza Abu'l-Fadl. In Miracles and Metaphors. Los Angeles: Kalimat Press.

Cole, Juan Ricardo. 1992. Iranian Millenarianism and Democratic Thought in the 19th Century. International Journal of Middle East Studies 24: 1-26. [CrossRef]

Cole, Juan Ricardo. 1998. Modernity and the Millennium: The Genesis of the Baha'i Faith in the Nineteenth-Century Middle East. New York: Columbia.

Curzon, George Nathaniel. 1892. Persia and the Persian Question. London: Longmans, Green, 2 vols.

Dabashi, Hamid. 2011. Shi'ism: A Religion of Protest. Cambridge: The Belknap Press of Harvard University Press.

Deleuze, Gilles, and Félix Guatarri. 1987. A Thousand Plateaux: Capitalism and Schizophrenia. Minneapolis: University of Minnesota Press.

Deringil, Selim. 2003. "They Live in a State of Nomadism and Savagery": The Late Ottoman Empire and the Post-Colonial Debate. Comparative Studies in Society and History 45: 311-42. [CrossRef]

Eldem, Edhem. 2015. The Ottoman Empire and Orientalism: An Awkward Relationship. In After Orientalism: Critical PFerspectives on Western Agency and Western Re-Appropriations. Edited by Francois Pouillon and Jean-Claude Vatin. Leiden: Brill, pp. 89-102.

Geaves, Ron. 2018. Muslims in Britain: Muslim Mission in an Age of Empire. London: Bloomsbury.

Gobineau, Joseph-Arthur. 1957. Religions et Philosophies Dans L'Asie Centrale. Paris: Gallimard.

Gobineau, Joseph-Arthur. 2009. Comte de Gobineau and Orientalism: Selected Eastern Writings. Edited by Geoffrey Nash. Translated by Daniel O'Donoghue. Abingdon: Routledge.

Hassan, Wail. 2011. Immigrant Narratives: Orientalism and Cultural Translation in Arab American and Arab British Literature. New York: Oxford University Press.

Horsley, Richard. 2003. Jesus and Empire: The Kingdom of God and the New World Disorder. Minneapolis: Fortress Press.

Keddie, Nikkie. 1981. Iran: Religion, Politics and Society: Collected Essays. London: Frank Cass.

King, Richard. 1999. Orientalism and Religion. London: Routledge.

Khanum, Ruhiyyih. 1969. The Priceless Pearl. London: Baha'i Publishing Trust.

Lambden, Stephen. 2002. Some Aspects of Isra'iliyyat and the Emergence of the Babi-Baha'i Intrepretation of the Bible. Ph.D. thesis, University of Newcastle, Newcastle, UK.

Lawrence, Bruce. 2006. The Qur'an: A Biography. Vancouver: Douglas and McIntyre.

Lawson, Todd. 2012. Baha'i Religious History. Journal of Religious History 36: 463-70. [CrossRef]

MacEoin, Denis. 1988. The Baha'is of Iran: Roots of Controversy. British Journey of Middle East Studies 14 1: 75-83.

MacEoin, Denis. 2009. The Messiah of Shiraz: Studies in Early and Middle Babism. Leiden: Brill.

MacEoin, Denis. 2012. Making the invisible visible: Introductory books on the Baha'i religion (the Baha'i Faith). Religion 43: 1-18. [CrossRef]

Macfie, Alexander Lyons. 2000. Orientalism: A Reader. Edinburgh: Edinburgh University Press.

Makdisi, Usama. 2002. Ottoman Orientalism. The American Historical Review 107: 768-96. [CrossRef]

McNamara, Brendan. 2017. Religious reformers in Britain at the turn of the twentieth century: The visits of Abdul Baha. Ph.D. thesis, University College Cork, Cork, Ireland.

Momen, Moojan. 1981. The Babi and Baha'i Religions: Some Contemporary Western Accounts. Oxford: George Ronald.

Nash, Geoffrey. 2014. Aryan and Semite in Ernest Renan's and Matthew Arnold's Quest for a Religion of Modernity. Religion and Literature 46: 25-50.

Nash, Geoffrey. 2019. Introduction. In Orientalism and Literature. Edited by Geoffrey P. Nash. New York: Cambridge University Press.

Nash, Geoffrey P. Forthcoming. Religion, Orientalism and Modernity: Mahdi Movements of Iran and South Asia. Edinburgh: Edinburgh University Press.

Paramore, Kiri, ed. 2016. Religion and Orientalism in Asian Studies. London: Bloomsbury.

Renan, Ernest. 1864. The Share of the Semitic People in the History of Civilization. In Studies of Religious History and Criticism. Translated by Octavius Brooks Frothingham. New York: G.W. Carleton, pp. 109-67.

Renan, Ernest. 1890. The Apostles. London: Mathieson.

Said, Edward W. 2003. Orientalism. London: Penguin.

Sharon, Moshe. 2004. Studies in Modern Religions, Religious Movements, and the Babi-Baha'i Faiths. Leiden: Brill.

Sheil, Lady. 1856. Glimpses of Life and Manners of Persia. London: John Murray.

Shoghi Effendi. 1932. The Dawn-Breakers: Nabil's Narrative of the Early Days of the Baha'i Revelation. Wilmette: Baha'i Publishing Trust.

Shoghi Effendi. 1944. God Passes By. Wilmette: Baha'i Publishing Trust.

Shoghi Effendi. 1961. The Promised Day Is Come. Wilmette: Baha'i Publishing Trust.

Storrs, Ronald. 1939. Orientations. London: Readers Union/Ivor Nicholson and Watson. 
Szurek, Emmanuel. 2015. “Go West": Variations to Kemalist Orientalism. In After Orientalism: Critical Perspectives on Eastern Agency and Western Re-Appropriations. Edited by Francois Pouillon and Jean-Claude Vatin. Leiden: Brill, pp. 103-20.

Thompson, Gardner. 2019. The Legacy of Empire: Britain, Zionism and the Creation of Israel. London: I.B.Tauris.

Viswanathan, Gauri. 2001. Power, Politics, and Culture: Interviews with Edward Said. New York: Vintage.

Weir, David. 2019. Nineteenth- and Twentieth-Century American Orientalism. In Orientalism and Literature. Edited by Geoffrey P. Nash. New York: Cambridge University Press, pp. 202-18.

Williams, Patrick. 2014. Postcolonialism and Orientalism. In Postcolonialism and Islam:Theory, Literature, Culture, Society and Film. Edited by Geoffrey Nash, Kathleen Kerr-Koch and Sarah Hackett. London: Routledge, pp. 48-61.

Zia-Ibrahimi, Reza. 2011. Self-Orientalization and Dislocation: The Uses and Abuses of the "Aryan" Discourse in Iran. Iranian Studies 44: 445-72. [CrossRef] 